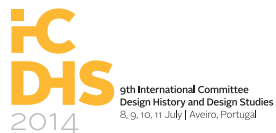

Blucher Design Proceedings Dezembro de 2014, Número 5, Volume 1

\title{
roundtable
}

\section{The European Province, part II: National approaches and wider issues relating to the global provinces}

chairs Anna Calvera + Helena Barbosa + Kjetil Fallan

In this roundtable, representatives from all the national design history societies will present their activities, points of view and continuing the discussion on geographies of design history which ICDHS has cultivated, this time on the role of national/regional/global frameworks. 